\title{
EXPERIMENTAL INVESTIGATION OF EFFECT OF OVERHANG TOOL LENGTH ON TOOL VIBRATION AND SURFACE ROUGHNESS
}

\author{
Ahmet Cekic, Kenan Muhamedagic, Maida Cohodar, \\ Derzija Begic-Hajdarevic \& Samra Biogradlija
}
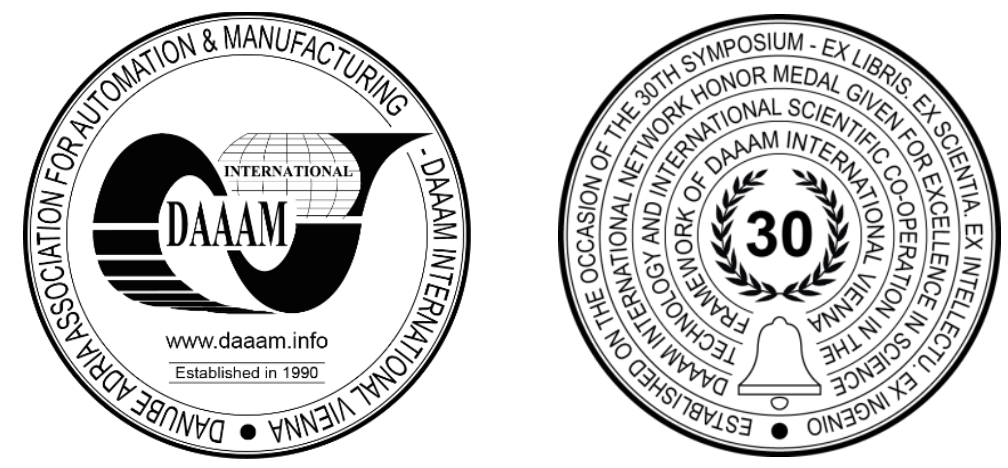

This Publication has to be referred as: Cekic, A[hmet]; Muhamedagic, K[enan]; Cohodar, M[aida]; Begic-Hajdarevic, D[erzija] \& Biogradlija, S [amra] (2019). Experimental Investigation of Effect of Overhang Tool Length on Tool Vibration and Surface Roughness, Proceedings of the 30th DAAAM International Symposium, pp.0184-0191, B. Katalinic (Ed.), Published by DAAAM International, ISBN 978-3-902734-22-8, ISSN 1726-9679, Vienna, Austria

DOI: $10.2507 / 30$ th.daaam.proceedings.024

\begin{abstract}
In this paper, the experimental investigation of effect of overhang tool length, depth of cut and feed rate on two responses such as tool vibration and surface roughness, by using Taguchi method and main effect plot was performed. C45E steel bars with diameter of $88 \mathrm{~mm}$ were machining using different values of overhang tool length, depth of cut and feed rate. Other process parameters were constant. Taguchi method was performed in order to identify the effect of each input process parameters on the analysed responses. The results were shown that the overhang tool length has a primary effect on the tool vibration and the surface roughness. The feed rate has secondary effect on the tool vibration, while the depth of cut has secondary effect on the surface roughness.
\end{abstract}

Keywords: turning process; tool vibration; surface roughness; overhang tool length.

\section{Introduction}

Turning is a form of machining, a material removal process, which is used to create rotational parts by cutting away unwanted material. Several machining parameters, such as cutting speed, feed rate, depth of cut, work piece material, tool overhang and cutting tool geometry have significant effect on the final product quality. Many researchers have studied the impact of these factors [1] and [2]. In addition, in order to achieve the proper quality of the final product, it is necessary to have the greatest stiffness of the system: machine-cutting tool-work piece. Due to the increasing of machining speed on machine tools, we have an increasing importance in studying the dynamic behaviour of the machine tool and the forces that occur on the same. In the turning operation, vibration is a frequent problem, which affects the result of the machining, and in particular, the surface finish and tool life. It is important to find out the appropriate parameters to obtain the high cutting performance. Today the standard procedure to avoid vibration during machining is by careful planning of the cutting parameters. The methods are usually based on experience and trial and error to obtain suitable cutting data for each cutting operation involved in machining a product. Many of previous researches are analysed influence of machining parameters on vibrations [3] and surface roughness [4]. 
The effect of turning parameters on vibration and surface roughness of Inconel alloy steel bar $\phi 40 \times 100 \mathrm{~mm}$, was experimentally examined in [5]. In this experiment, it has been observed that turning parameters like speed, feed and depth of cut has significant effect on vibration of cutting tool and surface roughness of work piece. It also shows that the vibration and surface roughness of work piece is directly proportional to speed, feed and depth of cut during turning operation. For investigate the effect of cutting speed, feed and depth of cut on the vibration of cutting tool during turning operation it's possible to use Finite Element Method [6]. It is observed that depth of cut is the most important factor in controlling the vibration of the cutting tool as it increases the longitudinal as well tangential cutting force leading surge in vibration, experiment as well FEA shows cutting speed plays negligible role in chatter effect. Effect of overhang tool length on vibration amplitude and surface roughness in turning AISI 304 was analysed in [7]. Optimized value of overhang length is suggested by Desirability Function Analysis (DFA) to get the minimum vibration amplitude and better surface quality. It is concluded that minimum length of tool overhang gives better machining performance in turning AISI 304. The relationship between induced vibration and surface roughness in turning of $41 \mathrm{Cr} 4$ alloy steel using Response Surface Methodology (RSM) was investigates in [8]. The levels of process cutting parameters in the study are limited to the following data: depth of cut $(1.0,2.0,3.0 \mathrm{~mm})$, cutting speed $(260,320,400 \mathrm{rpm})$, feed rate $(0.15,0.20,0.30 \mathrm{~mm} / \mathrm{rev})$, tool nose radius $(0,1,2 \mathrm{~mm})$, tool overhang $(50,55,60 \mathrm{~mm})$ and work piece overhang $(80,100,120 \mathrm{~mm})$. Experimental results have shown that induced vibration has significant impact on surface roughness which can be used to control the finished surface of a work pieces during mass production. The changing behaviour of vibration signals with varying cutting parameters (cutting speed, feed rate and depth of cut) for turning hardened AISI52100 steel has been studied in [9]. Experiments are planned and conducted as per Central composite rotatable design of Surface response methodology. The analysis of the results show that the acceleration amplitude Vx, Vy and Vz increases with increase in cutting speed and depth of cut. The vibration amplitude Vx, Vy and Vz initially increases as feed increases and, with further increase in feed, the vibration amplitude decreases. Based on the cutting parameters and tool vibration it is possible to predict the surface roughness [10]. The combined effects of cutting parameters and tool vibration on surface roughness were investigated while employing the analysis of variance (ANOVA). Prediction of surface roughness from cutting tool vibrations in hard turning of AISI D2 steel of different hardness with conventional and Wiper geometry CBN inserts, by using Regression Analysis and artificial Neural Network has reported in [11]. An empirical multiple regression models for prediction of surface roughness $(\mathrm{Ra})$ from the input variables in finishing turning of $42 \mathrm{CrMo} 4$ steel was developed in [12]. Cutting experiments and statistical analysis demonstrate that the model developed in this work produces smaller errors than those from some of the existing models. In [13] was shown optimization of surface roughness and vibration in turning of aluminium alloy AA2024 using Taguchi technique.

In this paper are analysed influence cutting parameters such as feed rate and depth of cut and the overhang tool length on two important indicators of quality such as surface roughness and tool vibration in turning process of carbon steel.

\section{Experimental procedure}

\subsection{Test material and measuring equipment}

The test material used in this experiment are C45E steel bars diameter $\phi 88 \mathrm{~mm}$. C45 steel is an unalloyed medium carbon steel which has $0.42 \%-0.5 \%$ carbon, as shown in Table 1 . It offers moderate tensile strengths, wear resistance and good machinability. C45 is generally supplied in an untreated or normalized condition with a typical tensile strength range 570 - 700 MPA and HB hardness range $170-210$.

\begin{tabular}{|c|c|c|c|c|c|c|c|c|c|}
\hline \multirow{2}{*}{ Steel name } & \multirow{2}{*}{$\begin{array}{c}\text { Steel } \\
\text { number }\end{array}$} & \multicolumn{8}{|c|}{ Chemical composition (percentages by mass) } \\
\cline { 3 - 11 } & $\mathbf{C}$ & $\begin{array}{c}\text { Si } \\
\text { max }\end{array}$ & $\mathbf{M n}$ & $\begin{array}{c}\mathbf{P} \\
\text { Max }\end{array}$ & $\begin{array}{c}\text { S } \\
\text { max }\end{array}$ & $\begin{array}{c}\mathbf{C r} \\
\max \end{array}$ & $\begin{array}{c}\text { Mo } \\
\max \end{array}$ & $\begin{array}{c}\text { Ni } \\
\max \end{array}$ \\
\hline $\mathrm{C} 45 \mathrm{E}$ & 1.1191 & $0.42-0.5$ & 0.4 & $0.5-0.8$ & 0.03 & 0.035 & 0.4 & 0.1 & 0.4 \\
\hline
\end{tabular}

Table 1. Chemical composition of C45E steel

For vibration measurements, the device PCE-VM 25 was used. The PCE-VM 25 can display the vibration quantities acceleration, velocity and displacement. Velocity and displacement are generated by single or double integration of the sensor acceleration signal. Furthermore, various frequency ranges can be selected (Table 2).

The display rate adjusts itself according to the selected quantity in order to ensure that the RMS does not fluctuate even at lower frequencies. In this paper, the numerical values of the vibration acceleration that the sensor reads in the frequency domain from $3 \mathrm{~Hz}$ to $1 \mathrm{kHz}$ are used for the purpose of reading vibrations at lower frequencies. The PCE-VM 25 specification is in accordance with ISO 2954 standards for machines that measure the vibration speed and is therefore suitable for measuring, among other things, machine tool vibration according to ISO 10816 standard. As the sensor uses an external piezoelectric accelerometer that is characterized by high precision and resolution. 


\begin{tabular}{|c|c|c|}
\hline Measuring parameters & Frequency range & Display rate \\
\hline Vibration acceleration & $0.2 \mathrm{~Hz}-10 \mathrm{kHz}$ & $5.6 \mathrm{~s}$ \\
\hline Vibration acceleration & $3 \mathrm{~Hz}-1 \mathrm{kHz}$ & $1.4 \mathrm{~s}$ \\
\hline Vibration acceleration & $1 \mathrm{~Hz}-10 \mathrm{kHz}$ & $1.4 \mathrm{~s}$ \\
\hline Vibration velocity & $2 \mathrm{~Hz}-1 \mathrm{kHz}$ & $1.4 \mathrm{~s}$ \\
\hline Vibration velocity & $10 \mathrm{~Hz}-1 \mathrm{kHz}$ & $1.4 \mathrm{~s}$ \\
\hline Vibration displacement & $5 \mathrm{~Hz}-200 \mathrm{~Hz}$ & $2.8 \mathrm{~s}$ \\
\hline
\end{tabular}

Table 2. Measurable vibration quantities

Tool vibration was measured in the direction of the main force of cutting. The vibration measurement, experimental setup was shown on Fig. 1.

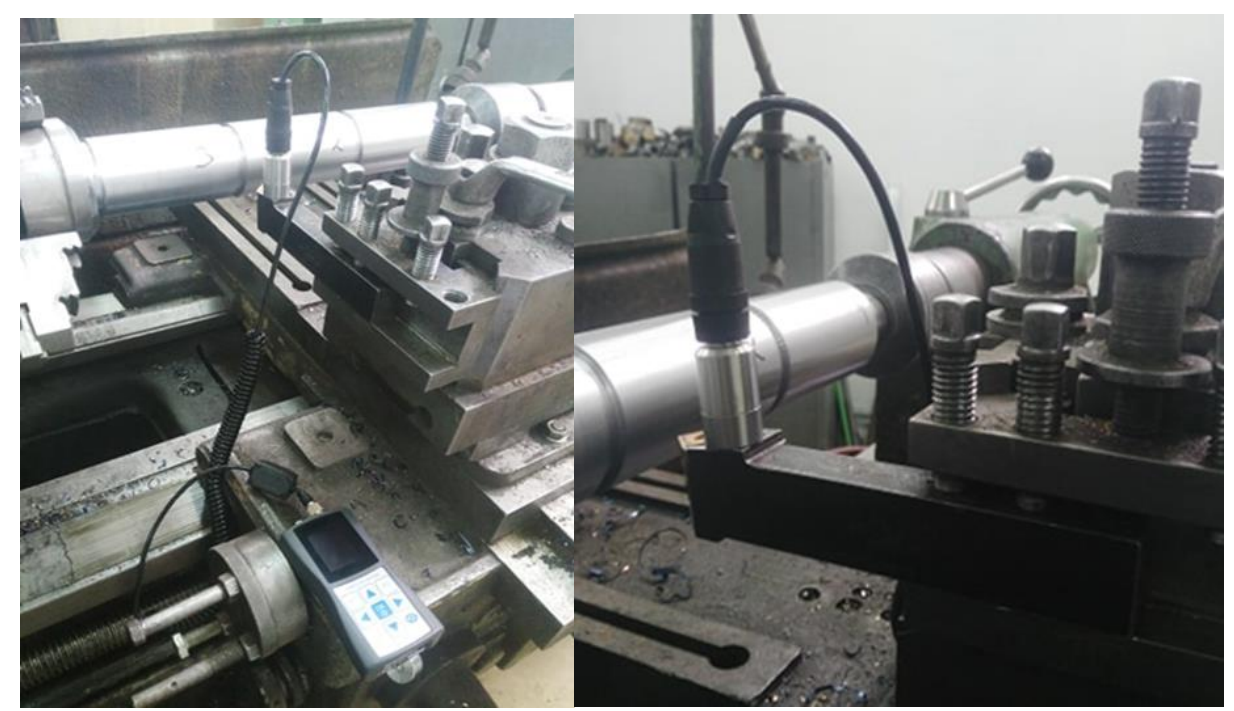

Fig. 1. Vibration measurement experimental setup

Measurement of surface roughness was performed on the Mitutoyo SJ-201 device. The surface roughness was measured in three places and the mean measured value of all individual measurements was taken. The measurements are repeated for each change in processing mode parameters. Surface roughness was measured in direction of feed (Fig. 2).

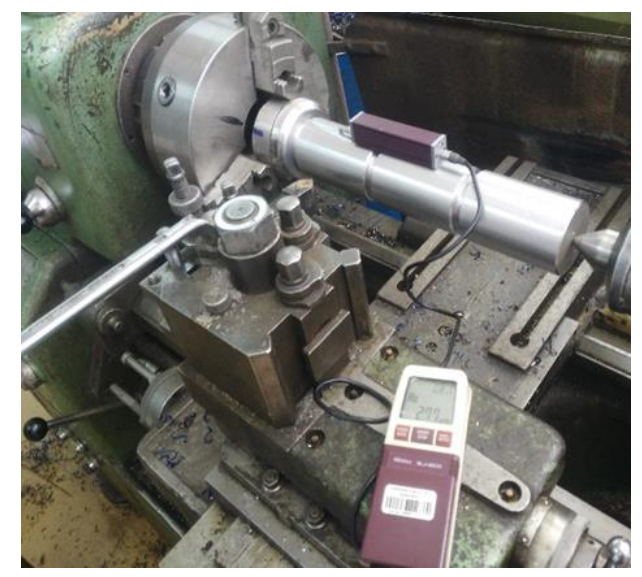

Fig. 2. Surface roughness measurement experimental setup 


\subsection{Design of experiments}

In this paper, a full experiment plan was used. Depth of cut, feed rate and overhang tool length are varied for this experiment. Other process parameters were constant. A total of 27 samples were sampled for each combination of overhang tool length, depth of cut and feed rate. The shape and dimensions of the work piece are shown on Fig. 3.

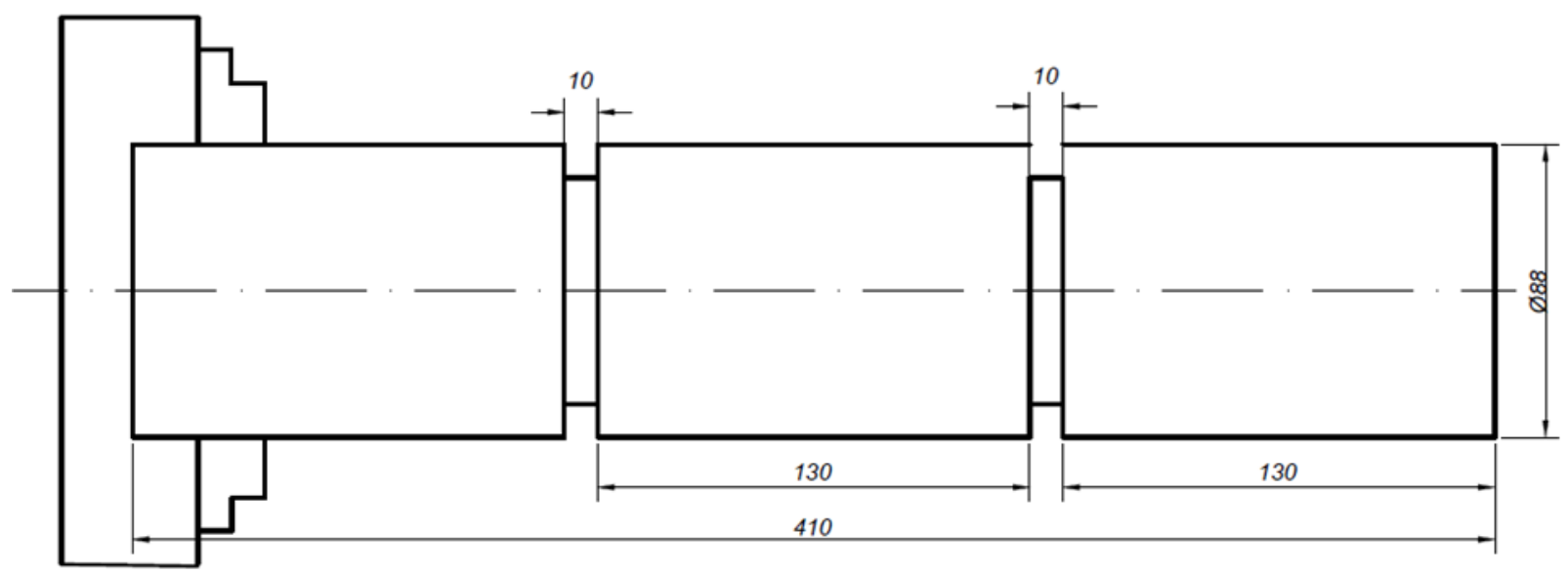

Fig. 3. Work piece dimensions

A test piece of $\mathrm{C} 45 \mathrm{E}$ material is clamped in three jaw chuck of lathe machine and initial rough cutting is done. Three different levels for each input parameter (overhang tool length, feed and depth of cut) are selected for the machining experiments. The turning parameters and their levels are summarized in Table 3 . Then $130 \mathrm{~mm}$ cut is taken for each combination of input parameters for parameters values in Table 4.

\begin{tabular}{|c|c|c|c|}
\hline \multirow{2}{*}{ Turning parameter } & \multicolumn{3}{|c|}{ Level } \\
\cline { 2 - 4 } & 1 & 2 & 3 \\
\hline $\begin{array}{c}\text { Overhang tool length, } \\
L[\mathrm{~mm}]\end{array}$ & 60 & 83 & 100 \\
\hline $\begin{array}{c}\text { Feed rate, } \\
f[\mathrm{~mm} / \mathrm{rev}]\end{array}$ & 0.07 & 0.14 & 0.214 \\
\hline $\begin{array}{c}\text { Depth of cut, } \\
a[\mathrm{~mm}]\end{array}$ & 0.5 & 1 & 1.5 \\
\hline
\end{tabular}

Table 3. Turning parameters and their levels

\begin{tabular}{|c|c|c|c|c|c|c|c|c|c|c|}
\hline $\begin{array}{c}\text { Overhang } \\
\text { tool length, } \\
L[\mathrm{~mm}]\end{array}$ & $\begin{array}{c}\text { Depth of cut, } \\
a[\mathrm{~mm}]\end{array}$ & \multicolumn{3}{|c|}{$\begin{array}{c}\text { Feed, } \\
{[\mathrm{mm} / \mathrm{rev}]}\end{array}$} & \multicolumn{3}{|c|}{$\begin{array}{c}\text { Vibration acceleration } \\
{\left[\mathrm{mm} / \mathrm{s}^{2}\right]}\end{array}$} & \multicolumn{3}{c|}{$\begin{array}{c}\text { Surface roughness, } \\
R_{a}[\mu \mathrm{m}]\end{array}$} \\
\hline 60 & 0.5 & 0.07 & 0.14 & 0.214 & 2.7 & 1.05 & 0.8 & 3.83 & 4.26 & 4.05 \\
\hline 60 & 1 & 0.07 & 0.14 & 0.214 & 1.84 & 1.51 & 1.59 & 2.99 & 3.35 & 3.03 \\
\hline 60 & 1.5 & 0.07 & 0.14 & 0.214 & 1.52 & 2.94 & 0.75 & 2.89 & 3.3 & 2.96 \\
\hline 83 & 0.5 & 0.07 & 0.14 & 0.214 & 1.48 & 2.57 & 1.32 & 2.37 & 2.34 & 3.54 \\
\hline 83 & 1 & 0.07 & 0.14 & 0.214 & 1.41 & 1.67 & 1.7 & 2.76 & 2.82 & 3.1 \\
\hline 83 & 1.5 & 0.07 & 0.14 & 0.214 & 1.63 & 1.57 & 2.3 & 2.7 & 2.98 & 2.65 \\
\hline 100 & 0.5 & 0.07 & 0.14 & 0.214 & 4.1 & 3.25 & 5.53 & 4.24 & 3.29 & 2.78 \\
\hline 100 & 1 & 0.07 & 0.14 & 0.214 & 9.7 & 4.2 & 3.5 & 2.4 & 3.54 & 3.55 \\
\hline 100 & 1.5 & 0.07 & 0.14 & 0.214 & 12.92 & 5.2 & 3.8 & 2.15 & 3.79 & 3.48 \\
\hline
\end{tabular}

Table 4. Experimental results 


\section{Results and discussions}

In turning operations, the most significant impact on the surface roughness has the tool vibrations that occur during of the cutting process as a result of various factors. In this work, most influential factors were analysed: overhang tool length, depth of cut and feed rate. From the above experimental result data, the value of tool vibration and also surface roughness of work piece results are plotted in a graph to give better understanding of results. The influence of cutting parameters on responses can be analysed by using 3-D response graph (Fig. 4).

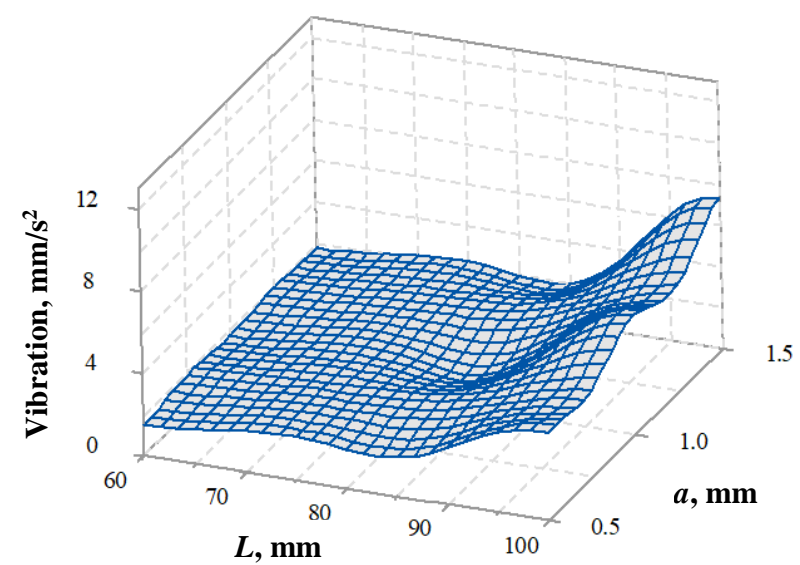

a) Effect of overhang tool length and depth of cut on vibration acceleration

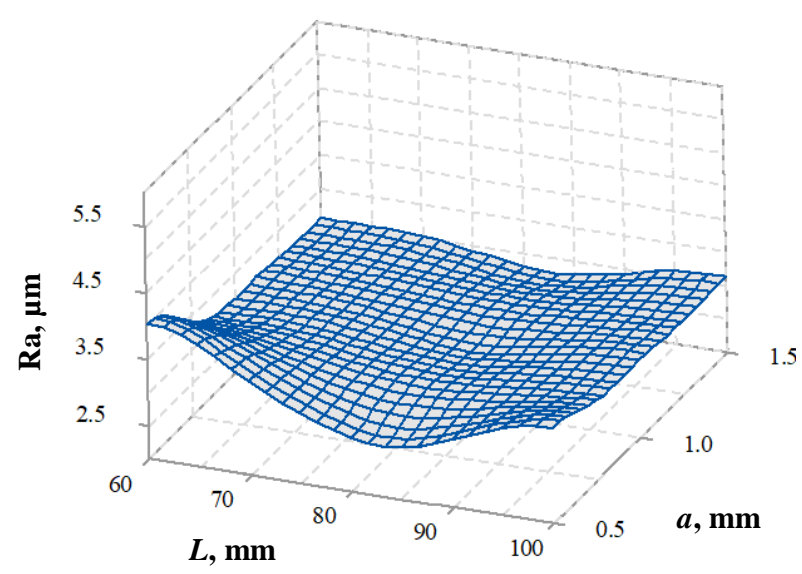

c) Effect of overhang tool length and depth of cut on surface roughness

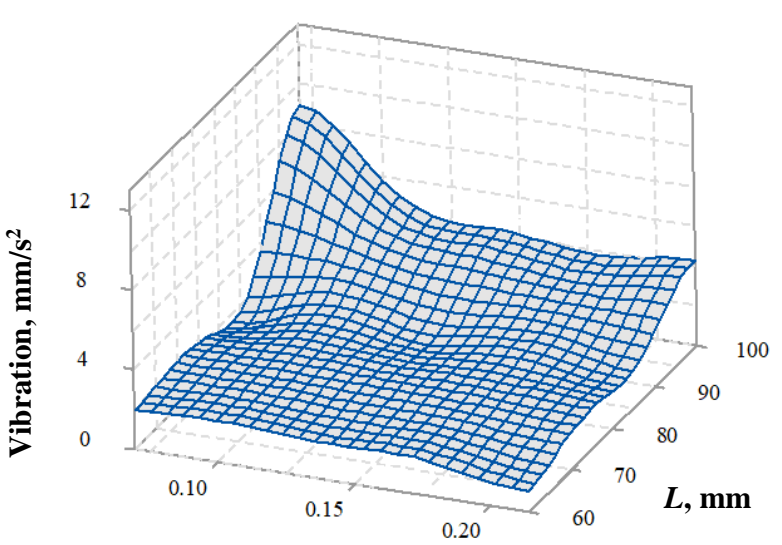

$f, \mathrm{~mm} / \mathrm{rev}$

b) Effect of overhang tool length and feed rate on vibration acceleration

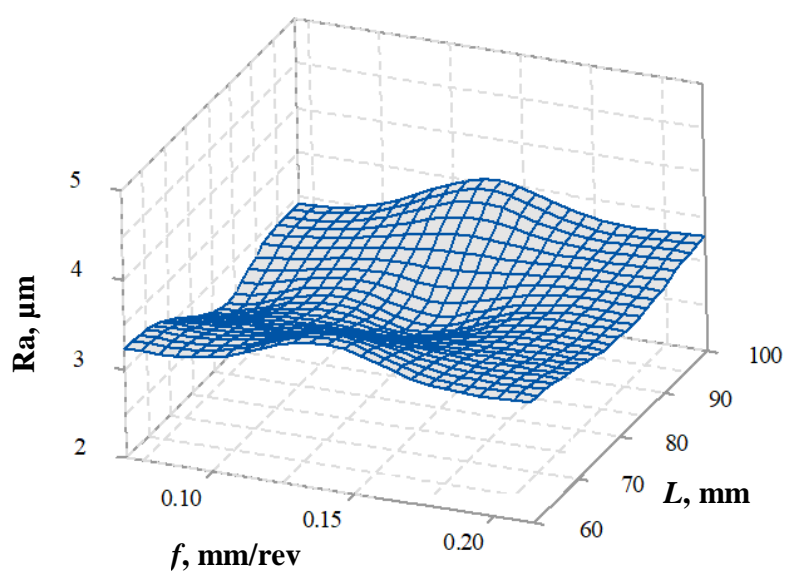

d) Effect of overhang tool length and feed rate on surface roughness

Fig. 4. Influence of input parameters on responses

3-D response graphs show the combined effect of depth of cut with overhang tool length $\left(a^{*} L\right)$, and feed rate with overhang tool length $\left(f^{*} L\right)$ on the tool vibration and the surface roughness. From this graphs it can be seen that overhang tool length, with various cutting parameters, has a significant influence on the tool vibration and surface roughness. Minimum tool vibration is found $0.8 \mathrm{~mm} / \mathrm{s}^{2}$ for the overhang tool length of $60 \mathrm{~mm}$, and maximum tool vibration is 12.92 $\mathrm{mm} / \mathrm{s}^{2}$ for the overhang tool length of $100 \mathrm{~mm}$. Also, with increased overhang tool length and tool vibration, surface roughness increases, except for the less value of feed rate (Fig. 4d), where the change in overhang tool length did not have a significant impact on the surface roughness.

For better understanding the individual impact of overhang tool length, feed rate and depth of cut on tool vibrations and surface roughness, response Table 5 and Table 6 , and main effect plot for vibration acceleration and surface roughness are shown on Fig. 5.

According to the results shown in Table 5 and Table 6, the overhang tool length has the most significant effect in reducing tool vibrations and surface roughness. For this case of vibration and surface roughness analysing, minimum value is better. From the main effect plot (Fig. 5) it is can be seen that shorter overhang tool length (60 mm) gives the 
best result for vibration acceleration. Increasing the overhang tool length, vibration acceleration of the tool increases too, especially for overhang tool length over $83 \mathrm{~mm}$. Depth of cut has the smallest impact on the tool vibration, and by increasing depth of cut there is slight increase in tool vibration. Increasing the feed rate from $0.07 \mathrm{~mm} / \mathrm{rev}$ to 0.214 $\mathrm{mm} / \mathrm{rev}$, tool vibration decreases. Minimum value of vibration acceleration have been achieved for $60 \mathrm{~mm}$ overhang tool length, $0.5 \mathrm{~mm}$ depth of cut and $0.214 \mathrm{~mm} / \mathrm{rev}$ feed rate.

\begin{tabular}{|c|c|c|c|}
\hline \multirow{2}{*}{ Level } & \multicolumn{3}{|c|}{ Cutting parameters } \\
\cline { 2 - 4 } & $\begin{array}{c}\text { Overhang tool } \\
\text { length }\end{array}$ & Depth of cut & Feed rate \\
\hline 1 & 1.633 & 2.533 & 4.144 \\
\hline 2 & 1.739 & 3.013 & 2.662 \\
\hline 3 & 5.800 & 3.626 & 2.366 \\
\hline$\Delta$ & 4.167 & 1.092 & 1.779 \\
\hline Rank & 1 & 3 & 2 \\
\hline
\end{tabular}

Table 5. Response table for vibration acceleration

\begin{tabular}{|c|c|c|c|}
\hline \multirow{2}{*}{ Level } & \multicolumn{3}{|c|}{ Cutting parameters } \\
\cline { 2 - 4 } & $\begin{array}{c}\text { Overhang tool } \\
\text { length }\end{array}$ & Depth of cut & Feed rate \\
\hline 1 & 3.407 & 3.411 & 2.926 \\
\hline 2 & 2.807 & 3.060 & 3.927 \\
\hline 3 & 3.247 & 2.989 & 3.238 \\
\hline$\Delta$ & 0.600 & 0.422 & 0.371 \\
\hline Rank & 1 & 2 & 3 \\
\hline
\end{tabular}

Table 6. Response table for surface roughness

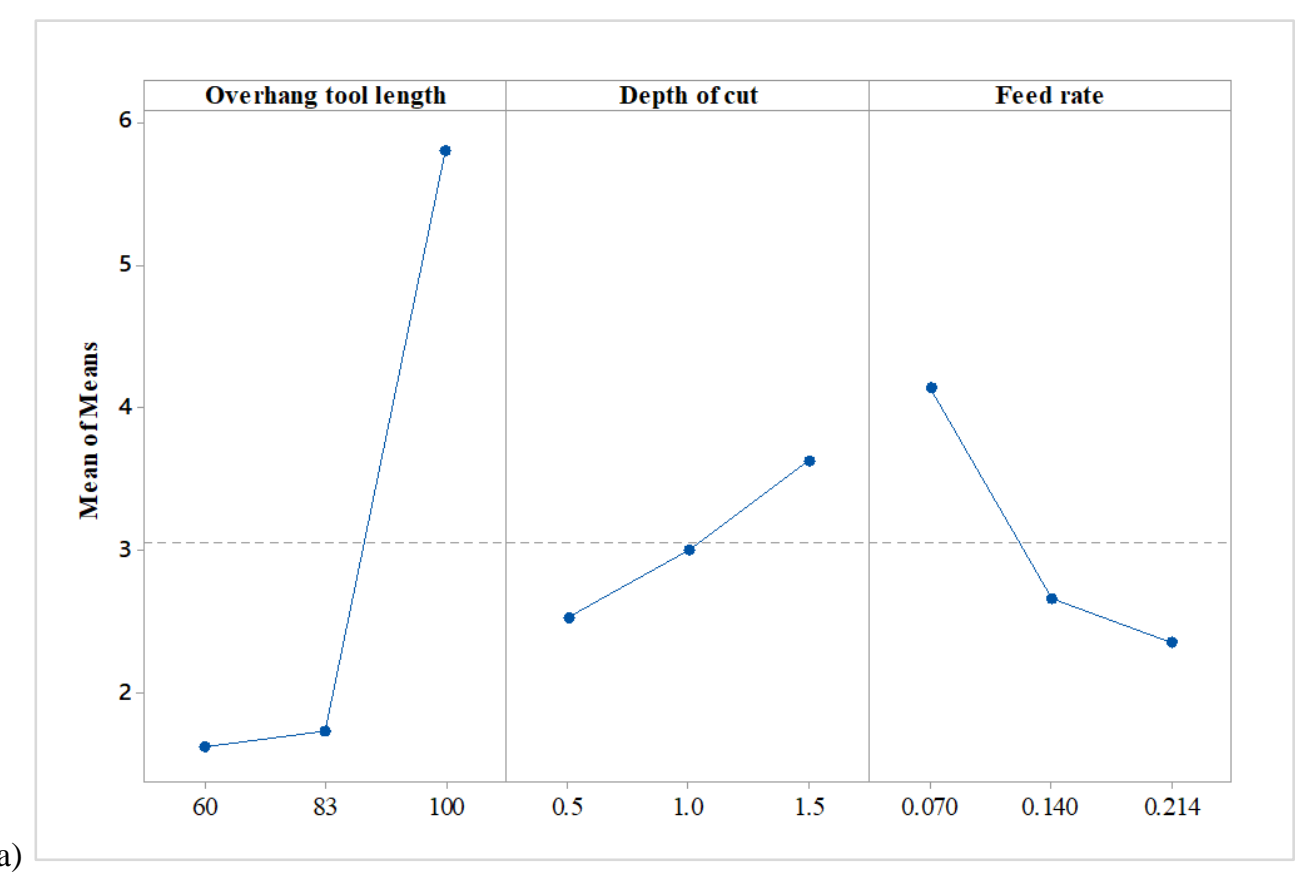




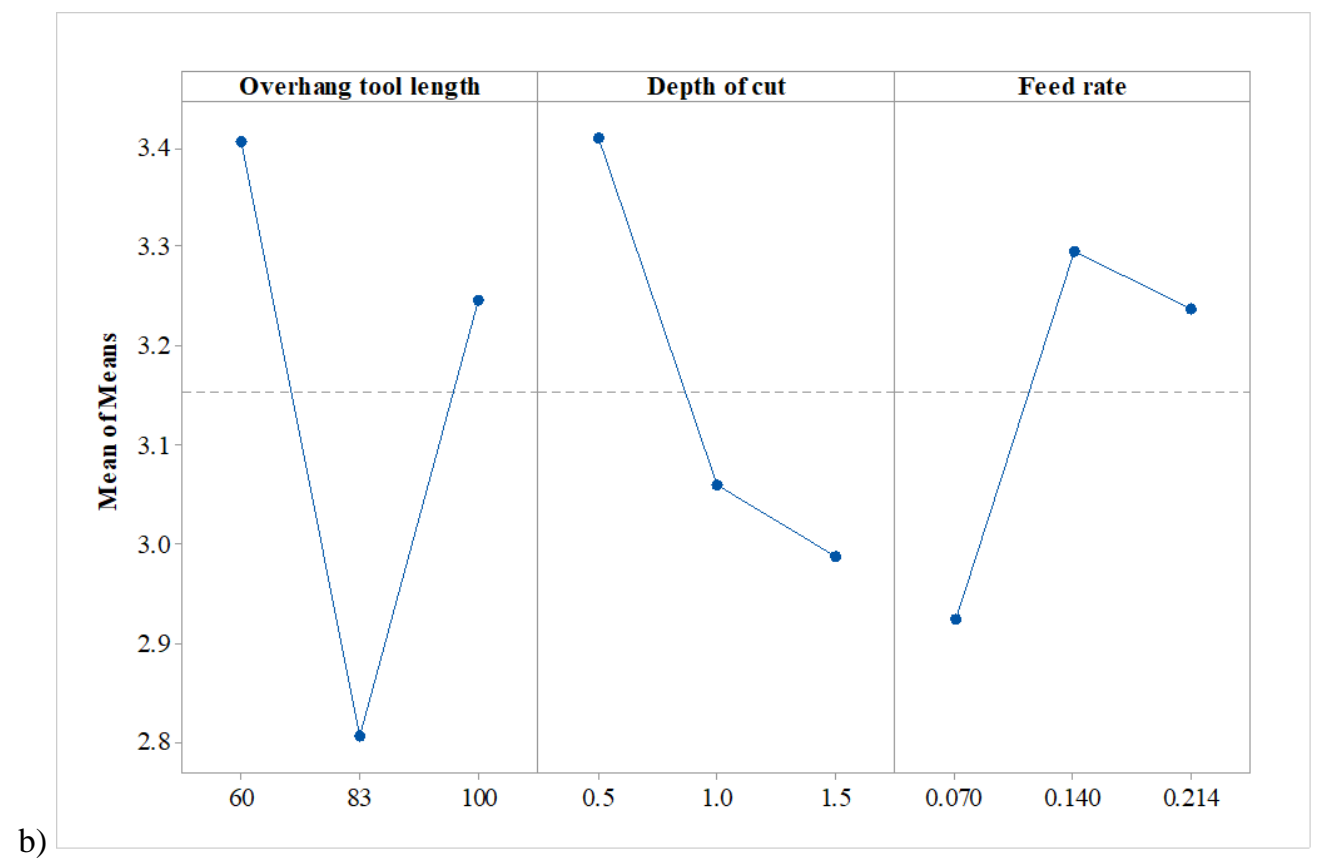

Fig. 5. Main effect plot for vibration acceleration (a) and surface roughness (b)

Increasing of the feed rate and decreasing of the depth of cut result in increased surface roughness. The best mean value of surface roughness has been achieved for $83 \mathrm{~mm}$ overhang tool length, $1.5 \mathrm{~mm}$ depth of cut and $0.07 \mathrm{~mm} / \mathrm{rev}$ feed rate.

\section{Conclusion}

The effect of overhang tool length with other turning parameters such as depth of cut and feed rate on tool vibration and surface roughness has been studied in this work. As each of three factors varied on three levels, so a total of 27 experiments were done. For each experimental run, vibration was measured in the direction of the main force of cutting and surface roughness was measured in direction of feed. From experimental results 3-D response graphs are drawn. Based on this graphs, it is observed that:

- The overhang tool length has a significant effect on the tool vibration and surface roughness, while the feed rate has secondary effect on the tool vibration, and the depth of cut has secondary effect on the surface roughness.

- Increasing the overhang tool length, vibration acceleration of the tool increases too, especially for overhang tool length over $83 \mathrm{~mm}$.

- Minimum value of vibration acceleration has been achieved for minimal overhang tool length $60 \mathrm{~mm}$, minimal depth of cut $0.5 \mathrm{~mm}$, and maximal feed rate $0.214 \mathrm{~mm} / \mathrm{rev}$.

- Best mean value of surface roughness has been achieved for $83 \mathrm{~mm}$ overhang tool length, $1.5 \mathrm{~mm}$ depth of cut and $0.07 \mathrm{~mm} / \mathrm{rev}$ feed rate.

The proposal for future research is that CNC machines can be used for experimentation to have the better control of the process variables and also parameters can be set to the desired accuracy. Also, other input parameters like as cutting speed, tool geometry, material and diameter of work piece, can be varied.

\section{Acknowledgments}

This work was supported by Ministry of Education and Science Federation of Bosnia and Herzegovina and Faculty of Mechanical Engineering University of Sarajevo. It is realized in framework of the project „Synergy of the reverse engineering and robotics“. The support is gratefully acknowledged.

\section{References}

[1] Clares, J.M.; Vazquez-Martinez, J.M.; Gomez-Parra, A.; Puerta, F.J. \& Marcos, M. (2016). Experimental methodology of evaluating workpieces surface integrity in dry turning of aerospace alloys. Proceedings of the 26th DAAAM International Symposium, pp.0849-0855, B. Katalinic (Ed.), Published by DAAAM International, ISBN 978-3-902734-07-5, ISSN 1726-9679, Vienna, Austria, DOI: 10.2507/26th.daaam.proceedings.118 
[2] Nosal, J.; Brezikova, K. \& Simkulet, V. (2017). Verification of combined cutting tool with linear cutting edge tool. Proceedings of the 28th DAAAM International Symposium, pp.1227-1233, B. Katalinic (Ed.), Published by DAAAM International, ISBN 978-3-902734-11-2, ISSN 1726-9679, Vienna, Austria, DOI: 10.2507/28th.daaam.proceedings. 171

[3] Gazi, A. A.; Ratnakar, D.; Sahoo, A. K.; Routara, B. C. \& Nanda, B. K. (2017). A Study on the Effect of Machining Parameters in Turning of Lead Alloy. Materials today: Proceedings, Vol. 4, Issue 8, pp. 7562-7572, ISSN: 22147853

[4] Begic-Hajdarevic, D.; Cekic, A. \& Kulenovic (2014). Experimental study on the high speed machining of hardened steel. Procedia Engineering, Vol. 69, pp. 291-295, ISSN: 1877-7058

[5] Shinde, R. \& Sonawane, S. A. (2018). Effect of speed, feed \& depth of cut on vibration and surface roughness during turning operation. International Journal of Mechanical and Production, Engineering Research and Development (IJMPERD), Vol. 8, Issue 4, pp. 819-826, ISSN: 2249-6890

[6] Rakesh, M. \& Nitin, M. (2017). Effect of speed, feed and depth of cut on vibration of cutting tool. International Journal of Innovative and Emerging Research in Engineering, Vol. 4, Issue 5, pp. 77-82, ISSN: 2394 - 5494

[7] Dilwar, F. \& Siddique, R. A. (2018). Analyzing the effect of overhang length on vibration amplitude and surface roughness in turning AISI 304. International Journal of Scientific \& Engineering Research, Vol. 9, Issue 6, pp. 173179, ISSN 2229-5518

[8] Eze, S. C.; Izelu, C. O.; Oreko, B. U. \& Edward, B. A. (2013). Experimental study of induced vibration and work surface roughness in the turning of $41 \mathrm{Cr} 4$ alloy steel using Response Surface Methodology. International Journal of Innovative Research in Science, Engineering and Technology, Vol. 2, Issue 12, pp. 7677-7683, ISSN: 2319-8753

[9] Ambhore, N.; Kamble, D. \& Chinchankiar, S. (2018). Prediction of cutting tool vibration and surface roughness in hard turning of AISI52100 steel. MATEC Web of Conferences 211, pp. 1-6, DOI: $10.1051 /$ matecconf/201821103011

[10] Hessainia, Z.; Belbah, A.; Yallese, M. A.; Mabrouki, T. \& Rigal, J. F. (2013). On the prediction of surface roughness in the hard turning based on cutting parameters and tool vibrations. Measurement, Vol. 46, ISSN: 1671-1681

[11] Sarnobat, S. S. \& Raval, H. K. (2018). Prediction of Surface Roughness from Cutting Tool Vibrations in Hard Turning of AISI D2 Steel of Different Hardness with Conventional and Wiper Geometry CBN Inserts. Journal of Applied Mechanical Engineering, Vol. 7, Issue 1, pp. 1-7, ISSN: 2168-9873

[12] Neseli, S.; Yalcin, G. \& Yaldiz, S. (2018). Surface Roughness Estimation for Turning Operation Based on Different Regression Models Using Vibration Signals. International Journal of Intelligent Systems and Applications in Engineering, Vol. 6, No. 4, pp 282-288, ISSN: 2147-6799

[13] Aleksandrovich, R. V. \& Siamak, G. (2013). Optimization of Surface Roughness and Vibration in Turning of Aluminum Alloy AA2024 Using Taguchi Technique. International Journal of Mechanical and Mechatronics Engineering, Vol. 7, No. 11, pp. 869-878, ISSN: 2227-2771 